\title{
Production of Enzyme and Growth of Aspergillus oryzae S. on Soybean Koji
}

\author{
Chuenjit Chancharoonpong, Pao-Chuan Hsieh, and Shyang-Chwen Sheu
}

\begin{abstract}
Soybean koji is an important ingredient for traditional fermented food in South-East Asia and East Asia. It provides large amount of enzyme from koji mold, Aspergillus oryzae S., to digest nutrients in substrates. This study aimed at production of certain enzymes in soybean koji and potential to be applied for accelerating fish sauce fermentation. Koji containing $60 \%$ soybean was used as substrate to investigate the enzyme production by $A$. oryzae $S$. The growth of this mold was enumerated by potato dextrose agar. The mycelium development of $A$. oryzae $\mathrm{S}$. was observed by scanning electron microscope. During koji production, $\mathrm{pH}$ of soybean koji increased from 6.32 to 6.07. It was caused by extracellular proteins production. The highest neutral protease, alkaline protease and amylase activities were $84.38,41.35$ and 200 unit/g of dry weight, respectively. Moreover, growing of enzyme activities on soybean koji correlated with the growth of this mold. Electron micrograph showed that spores of $A$. oryzae $S$. were formed after $48 \mathrm{~h}$ of cultivation period. Additionally, the highest enzymes activities were also shown in this stage.
\end{abstract}

Index Terms-Amylase, Aspergillus oryzae S., protease, soybean koji

\section{INTRODUCTION}

Koji is cooked wheat and/or soybean that has been inoculated with a fermentation culture or koji mold. The first step in making fermented foods, such as soy sauce, miso, mirin, sake, and other fermented foods is creating the koji. During the koji making, the koji mold (Aspergillus oryzae S.) produces a variety of amylases and proteases to break down carbohydrates and proteins in wheat and soybean [1]-[3].

A. oryzae $\mathrm{S}$. is a filamentous fungus, which has an ability to secrete large amounts of hydrolytic enzymes. It is widely used in the manufacture of traditional fermented soy sauce in Asia. The extracellular proteins in soybean koji inoculated with $A$. oryzae S. contain different protein profiles including neutral and alkaline protease, amylase, glutaminase, and metallopeptidase [4]. Moreover, A. oryzae S. is genomically well characterized and considered to be a safe organism for production of food enzymes because it lacks expressed sequence tags for the genes responsible for aflatoxin

Manuscript received April 26, 2012; revised May 29, 2012.

Chuenjit Chancharoonpong is with the Department of Tropical Agriculture and International Cooperation, National Pingtung University of Science and Technology, Pingtung 91201, Taiwan and Kasetsart University, Bangkok 10900, Thailand (e-mail: csncjc@ku.ac.th).

P. C. Hsieh and S. C. Sheu are with the Department of Food Science, National Pingtung University of Science and Technology, Pingtung 91201, Taiwan (e-mail: pchsieh@mail.npust.edu, ssheu@mail.npust.edu.tw). production [5].

In traditional fermentation, solid-state fermentation (SSF) is suitable for fungi growth because of its low moisture content and permitting of the penetration of fungi mycelium through the solid substrates. Fungal mycelium can penetrate into the solid substrate as 4 layers of mycelium penetration. The first layer is areal hyphae, followed by aerobic wet hyphae and anaerobic wet hyphae, the last layer is penetrative hyphae [6]. Low humidity in a solid-state fermentation makes microorganisms more capable of producing certain enzymes and metabolites which usually will not be produced in a submerge fermentation [6], [7].

As same as traditional soy sauce production, protease and amylase are also used to hydrolyze substrate in fish sauce production. During fermentation, enzymatic digestion may range from 6 months for small fish to 18 months for larger fish. The liquid removed from the fermenting fish contains an abundance of peptides, amino acids, ammonia, volatile fatty acids, and other nutrients are considered the highest quality product [8], [9].

However, this process takes up to one to two years for fermentation. Accordingly, there are many acceleration techniques, such as acid or alkaline hydrolysis, enzyme degradation, and bacterial inoculation [10], [11]. The acceleration of fish sauce fermentation will be advantageous if the fermentation period can be reduced. In this study, we investigated the production of certain enzymes in koji containing mixture of soybean and wheat bran which have been used in soy sauce production and the potential to be applied for accelerating fish sauce production. Moreover, the growth of A. oryzae S. during koji fermentation was also investigated.

\section{MATERIALS AND METHODS}

\section{A. Koji Preparation}

Sixty percent of soybean was soaked in water for 6-8 h then autoclaved at $121^{\circ} \mathrm{C}$ for $40 \mathrm{~min}$. Forty percent of wheat bran was roasted to dark brown and broken. The $32 \%$ of total wheat bran was ground to powder and mixed with culture before spreading to raw material to ensure mixing through of raw material. Spores of A. oryzae S. NPUST-FS-206-A1 $(0.1 \%)$ were inoculated into raw material and incubated at $30^{\circ} \mathrm{C}$ for $72 \mathrm{~h}$. Sheet cloth was sprayed with water and covered on fermented matter to protect moisture evaporation during cultivation. Koji was agitated every $12 \mathrm{~h}$ to released heat. 


\section{B. Enzyme Extraction}

The fermented matter was mixed with $0.1 \mathrm{M}$ phosphate buffer (pH 6.9) (1:2 w/v) using a shaking incubator (150 rpm, $\left.30^{\circ} \mathrm{C}, 30 \mathrm{~min}\right)$. The supernatant was collected as crude enzyme extract by centrifugation at $10,000 \mathrm{xg}, 4^{\circ} \mathrm{C}$ for 15 $\min$.

\section{Analytical Methods}

The moisture content of a fermented sample was determined by infrared moisture determination balance (FD-720, Kett Electric Laboratory, Tokyo, Japan). The fermented matter was mixed with deionized water $(1: 2 \mathrm{w} / \mathrm{v})$ by blender and the $\mathrm{pH}$ value was measured by $\mathrm{pH}$ meter (DKK-TOA, HM-25G, Japan).

Casein solution $(0.65 \%)$ in $0.05 \mathrm{M}$ phosphate buffer ( $\mathrm{pH}$ 6.9) and $0.05 \mathrm{M}$ carbonate buffer ( $\mathrm{pH} \mathrm{10)}$ were used as a substrate to analyze neutral and alkaline protease activity, respectively. One $\mathrm{mL}$ of crude enzyme extract and $5 \mathrm{~mL}$ of casein were mixed and incubated at $30^{\circ} \mathrm{C}$ for $10 \mathrm{~min}$. The reaction was arrested by adding $5 \mathrm{~mL}$ of trichloroacetic acid (TCA) and incubated for $30 \mathrm{~min}$. After centrifugation at $10,000 \mathrm{xg}$ for $10 \mathrm{~min}$ at $4^{\circ} \mathrm{C}$, the supernatant was collected. The supernatant $(2 \mathrm{~mL})$ was reacted with $5 \mathrm{~mL}$ of $500 \mathrm{mM}$ $\mathrm{Na}_{2} \mathrm{CO}_{3}$ and $1 \mathrm{~mL}$ of five-fold diluted Folin-Ciocalteau reagent for $10 \mathrm{~min}$. Absorbance was read against a blank at $660 \mathrm{~nm}$. One unit of enzyme activity was defined as the amount of enzyme that liberated $1 \mu \mathrm{g}$ of tyrosine per minute under assay conditions [12].

Amylase activity was measured with $1.0 \%$ soluble starch in $0.1 \mathrm{M}$ sodium acetate buffer $(\mathrm{pH} 5.0)$ as a substrate. One $\mathrm{mL}$ of crude enzyme extract and $1 \mathrm{~mL}$ of soluble starch were mixed and incubated at $30^{\circ} \mathrm{C}$ for $10 \mathrm{~min}$. After incubation, one $\mathrm{mL}$ of 3,5-dinitrosalicylic acid was added, reacted in a boiling water bath for $15 \mathrm{~min}$, cooled to room temperature and added with $9 \mathrm{~mL}$ of deionized water. The amylase activity was analyzed spectrophotometrically at $540 \mathrm{~nm}$. One unit of enzyme activity was defined as the amount of enzyme that released $1 \mathrm{mM}$ of reducing sugar as maltose per minute under the assay condition [13]. The enzyme activity was reported per gram of dry koji used in the initial extraction. All the samples were analyzed in triplicate.

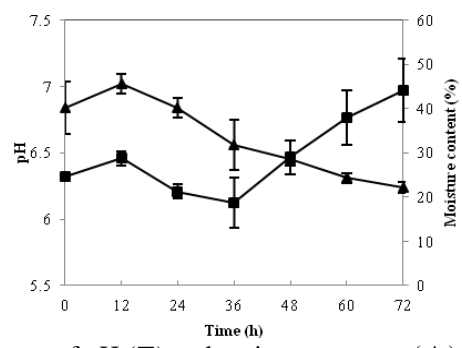

Fig. 1. Change of $\mathrm{pH}(\boldsymbol{\square})$ and moisture content $(\boldsymbol{\Delta})$ during koji production

\section{Growth of Microorganism.}

At different time intervals, koji samples were taken and blended with $0.1 \%$ peptone water for $20 \mathrm{sec}$. The growth of microorganism was enumerated by pour plate technique using plate count agar for total viable count and potato dextrose agar for growth of mold.

\section{E. Scanning Electron Microscope}

Samples were fixed by $3 \%$ glutaraldehyde in $0.1 \mathrm{M}$ phosphate buffer ( $\mathrm{pH} 7.0$ ), dried by a critical point dryer (HCP-2, Hitachi, and Japan) and mounted on stub holders. The samples were then coated with gold in a coater (E-1010,

Hitachi, Japan) and investigated on a scanning electron microscope (Model S-3000N, Hitachi, Japan).

\section{F. Statistical Analysis}

Data was analyzed using statistical analysis system (SPSS, version 13) for correlation analysis between microbial growth and enzymes production.

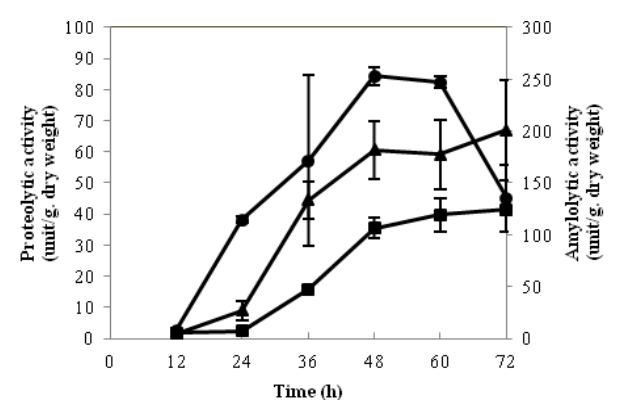

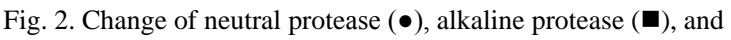
amylase activity $(\boldsymbol{\Delta})$ during soybean koji production

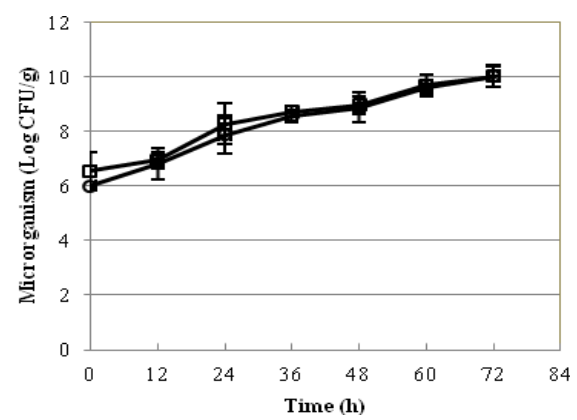

Fig. 3. Change of total viable count ( $\square$ ), and mold (०) during soybean koji Production

\section{RESULTS AND DISCUSSIONS}

\section{A. Physical Properties of Koji}

As shown in Fig. 1, the initial pH of koji was 6.32, then the $\mathrm{pH}$ decreased to 6.12 after $24 \mathrm{~h}$ of cultivation. However, it increased to 6.97 at the end of cultivation period. Similar results have also been reported for $A$. oryzae in soy sauce koji containing $75 \%$ soybean koji that the increasing of $\mathrm{pH}$ of fermented matter was due to the microbial metabolic activities especially various extracellular proteins production [4].

Moisture in substrates brings a suitable water activity and swells substrates for mold growth [14]. The results showed that the initial moisture content of koji was $40 \%$ then increased to $45 \%$ at $12 \mathrm{~h}$ cultivation. However, it decreased to $22 \%$ after $72 \mathrm{~h}$ (Fig. 1). However, the high moisture content at the beginning of fermentation period resulted in decreasing the porosity of substrates and reduction of heat transfer. Consequently, low enzymes activities at the beginning of cultivation period (Fig. 2) might be caused by the increasing of temperature (data not shown) [15]. 


\section{B. Enzyme Production}

The changes of neutral protease, alkaline protease and amylase production during soybean koji production were investigated (Fig. 2). Neutral protease activities on soybean koji increased rapidly after $12 \mathrm{~h}$ of cultivation. At $48 \mathrm{~h}$ of fermentation, soybean koji showed the highest neutral protease activity at 84.38 unit/g of dry weight. However, reason of decreasing of neutral protease activity after $60 \mathrm{~h}$ could be the limitation of nutrients and variation of $\mathrm{pH} \quad$ (Fig. 1) [12]. On the contrary, alkaline protease activity was detected only a very small amount during the first $24 \mathrm{~h}$. After that time, the activity was slightly increased; however it was lower than those of neutral protease. The high activity of alkaline protease was shown after $48 \mathrm{~h}$ of cultivation period. It might be cause by increasing of $\mathrm{pH}$ of koji (Fig. 1). The highest alkaline protease activity was shown at the end of cultivation period at 41.35 unit/g of dry weight. Amylase activity was rapidly increased after $24 \mathrm{~h}$ of cultivation period. However, amylase activity remained for the last $24 \mathrm{~h}$ of cultivation. Finally, it showed the highest activity for 200 unit/g of dry weight, at $72 \mathrm{~h}$ of cultivation period. Additionally, the results indicated that increasing of $\mathrm{pH}$ after $48 \mathrm{~h}$ of cultivation period (Fig. 1) was due to the production of various enzymes from A. oryzae S. These similar results were explained that production of enzymes required amino acids by digesting proteins in substrate. A. oryzae can use a pool of nitrogen sources in soybean to produce extracellular proteins. Soybean contains high content of nitrogen to be a good substrate to produce proteolytic enzymes. Moreover, the intensity of proteins was deduced by the intensity of time dependence by digesting nutrients from substrates [4], [12], [13].

\section{Growth of A. oryzae S. During Koji Production}

The growth of microorganism on soybean koji was enumerated by plate count technique. The initial cultures on soybean koji were 6.0 and $6.5 \mathrm{Log} \mathrm{CFU} / \mathrm{g}$ of koji for mold and total count, respectively. It was shown that there were few of bacteria contaminated from substrates at the beginning of cultivation. The growth of culture increased continuously during soybean koji production then reached to $10 \mathrm{Log}$ $\mathrm{CFU} / \mathrm{g}$ of koji at the end of cultivation period. Moreover, the results indicated that the most of survival cells on soybean koji were mold. The number of total viable count and molds were also similar (Fig. 3).

TABLE I: THE CORRELATION ANALYSIS BETWEEN MICROBIAL GROWTH ANDNEUtRal Protease, ALKaline ProteAse, AND AMYLASE

\begin{tabular}{cc}
\multicolumn{2}{c}{ PRODUCTION } \\
\hline Enzyme & Correlation coefficients \\
\hline Neutral protease & $0.827^{*}$ \\
Alkaline protease & $0.899^{* *}$ \\
Amylase & $0.925^{* *}$ \\
\hline
\end{tabular}

* Correlation is significant at the 0.05 level (2-tailed).

** Correlation is significant at the 0.01 level (2-tailed).

The correlations between microbial growth and enzyme production were analyzed (Table I). For neutral protease, correlation coefficient was $0.827(\mathrm{P}<0.05)$. Alkaline protease and amylase activity showed high correlation coefficients to growth. There were 0.899 and 0.925 , respectively $(\mathrm{P}<0.01)$. The results indicated that it was significant positive correlated between microbial growth and enzyme production.

Moreover, the growth of $A$. oryzae $\mathrm{S}$. during koji production was also observed by a scanning electron microscope. As shown in Fig. 4, A. oryzae S. grew continuously during soybean koji production. There was no spore forming of mold at the beginning of cultivation. However, spore forming of mold was observed after $48 \mathrm{~h}$. The growth of mold also showed the contrasting relation with the moisture content (Fig. 1). The decrease of moisture content in koji is due to the utilization of water in substrate by mold to generate mycelia [14].

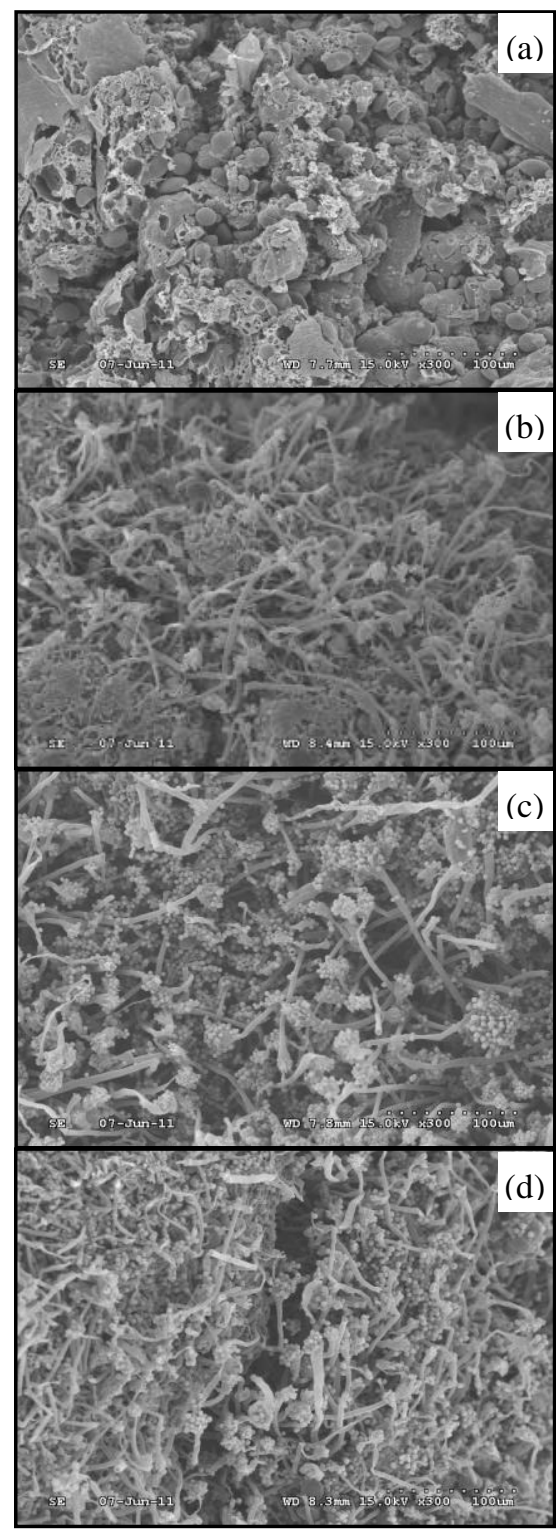

Fig. 4. Scanning electron micrographs of mycelium propagation on soybean koji fermentation, at $0 \mathrm{~h}$ (a), $24 \mathrm{~h}$ (b), $48 \mathrm{~h}$ (c) and $72 \mathrm{~h}$ (d)

Furthermore, the increasing of enzyme activity was also related to the growth of A. oryzae S. (Fig. 2). Additionally, the results showed that neither high content of enzyme activity nor spore forming of mold was observed at the beginning of cultivation $(24 \mathrm{~h})$. However, both of spores formation and the highest enzyme activities were found at $48 \mathrm{~h}$ of cultivation. It indicated that protease production was followed by the development of mycelium. There was similar 
results reported that growth of mold and enzyme production was correlated. A. niger showed the correlation between development of conidia and protease production during the fermentation period [16]. Moreover, our results indicated that high activities of various enzymes were also related to sporulation of mold (Fig. 2 and 4). The reason was reported that the asexual cycle or spore forming is related to the secondary metabolite production, such as enzyme and organic acid [3].

\section{CONClusion}

The results indicated that production of enzymes from $A$. oryzae S. was related to the physical properties of soybean koji during cultivation. Moreover, the growth of fungi showed the high correlation with enzyme production. Furthermore, development of mycelium was also related to the increasing of enzyme production. Particularly, both the spore forming stage of $A$. oryzae $\mathrm{S}$. and the highest enzyme production were at $48 \mathrm{~h}$ of cultivation period. It can summarize that fermented soybean koji at $48 \mathrm{~h}$ might be used as an activated enzyme source to accelerate fish sauce fermentation.

\section{ACKNOWLEDGMENT}

We would like to thank Dr. Tsair-Bor Yen from Department of Tropical Agriculture and International Cooperation, National Pingtung University of Science and Technology for availing the electron microscope facility.

\section{REFERENCES}

[1] T. C. Huang, and D. F. Teng, "Soy sauce: manufacturing and biochemical changes," in Handbook of Food and Beverage Fermentation Technology, Y. H. Hui, L. M. Goddik, A. S. Hansen, J. Josephsen, W. K. Nip, P. S. Stanfield, and F. Toldra, Ed. New York: Marcel Dekker, 2004.

[2] T. Suganuma, K. Fujita, and K. Kitahara, "Some distinguishable properties between acid-stable and neutral types of $\alpha$-amylase from acid-producing koji,” J. Biosci. Bioeng., vol. 104, no. 5, pp.353-362, 2007.

[3] O. P. Ward, W. M. Qin, J. Dhanjoon, J. Ye, and A. Singh, "Physiology and biotechnology of Aspergillus," Adv. App. Microbiol, vol. 58, pp. 1-55, 2006.

[4] Y. Liang, L. Pan, and Y. Lin, "Analysis of extracelular proteins of Aspergillus oryzae grown on soy sauce koji," Biosci. Biotechnol. Biochem, vol. 73, no. 1, pp. 192-195, 2009.

[5] M. Machida, K. Asai, M. Sano, T. Tanaka, T. Kumagai, G. Terai, and et al, "Genome sequencing and analysis of Aspergillus oryzae," Nature, vol. 43, pp. 1157-1161, 2005.

[6] R. Biesebeke, G. Ruijter, Y. S. P. Rahardjo, M. J. Hoogschagen, M. Heerikhuisen, A. Levin, and et al., "Aspergillus oryzae in solid-state and submerged fermentations progress report on a multi-disciplinary Project," FEM Yeast Research, vol. 2, pp. 245-248, 2002.

[7] H. Imanaka, S. Tanaka, B. Feng, K. Imamura, and K. Nakanishi, "Cultivation characteristic and gene expression profiles of Aspergillums oryzae by membrane-surface liquid culture, shaking-flask culture, and agar-plate culture," J. Biosci. Bioeng, vol. 109, no. 3, pp. 267-273, 2010.

[8] M. P. Doyle and L. R. Beuchat, Food Microbiology: Fundamentals and Frontiers. Washington, D.C: ASM Press, pp. 1038, 2007.

[9] J. J. Jiang, Q. X. Zeng, A. W. Zhu, and L. Y. Zhang, "Chemical and sensory changes associated Yu-lu fermentation process - A traditional Chinese fish sauce," Food Chemistry, vol. 104, pp. 1629-1634, 2007.

[10] J. Yongsawatdigul, S. Rodrong, and N. Raksakulthai, "Acceleration of Thai fish sauce fermentation using proteinases and bacterial starter cultures," J. Food Sci., vol. 72, no. 9, pp. M382-390, 2007.

[11] W. Xu, G. Yu, C. Xue, Y. Xue, and Y. Ren, "Biochemical changes associated with fast fermentation of squid processing by-products for low salt fish sauce," Food Chem., vol. 107, pp. 1597-1604, 2008.

[12] M. J. Garcia-Gomez, S. H. Ochoa, O. L. Corral, and L. A. P. Barragan, "Advantages of a proteolytic extract by Aspergillus oryzae from fish flour over a commercial proteolytic preparation," Food Chem, vol. 112 pp. 604-608, 2009.

[13] J. Chutmanop, S. Chuichulcherm, Y. Chisti, and P. Srinophakun, "Protease production by Aspergillus oryzae in solid-state fermentation using agroindustrial substrates," J. Chem. Technol. Biotechnol., vol. 83, pp. 1012-1018, 2008.

[14] H. Narahara, Y. Koyama, T. Yoshida, S. Pichangkura, R. Ueda, and H Taguchi, "Growth and enzyme production in solid-state culture of Aspergillus oryzae," J. Ferment. Technol., vol. 60, no. 4, pp. 311-319, 1982.

[15] A. Pandey, "Solid-state fermentation," Biochem. Eng. J., vol. 13, pp. 81-84, 2003.

[16] V. E. Sanchez and A. M. R. Pilosof, "Protease-conidia relationships of Aspergillus niger grown in solid state fermentation," Biotechnol. Letters, vol. 22, pp. 1629-1633, 2000. 